\title{
PENDIDIKAN KEWIRAUSAHAAN BAGI MAHASISWA PROGRAM STUDI TEOLOGI STT STAR'S LUB UNTUK KEMANDIRIAN FINANSIAL GEREJA
}

\author{
Mona Lintong, Ermin Alperiana Mosooli \\ Leo Mardani Runduingan, Lefran \\ Sekolah Tinggi Teologi Star's Lub Luwuk Banggai \\ monalintong@gmail.com
}

\begin{abstract}
The Theological Department of Star's Lub Theological College (SLTC) has organized entrepreneurship education. One of the goals is to equip students to develop church entrepreneurship if they become pastors in the future. This study aims to determine the extent to which entrepreneurship education can provide students with the ability to build church financial independence as part of church entrepreneurship. The research was conducted in two stages by combining qualitative and quantitative methods. The first stage examines the entrepreneurial abilities of 12 final semester students who have completed entrepreneurship education, focusing on knowledge, skills, and entrepreneurial character. The method used is quantitative. The second stage uses a qualitative approach by examining the entrepreneurship education program organized by the Theological Department. The informants involved were the Chairperson of SLTC, Deputy Head of Academic Affairs of SLTC, and lecturers in entrepreneurship courses. The results showed that the final semester students of SLTC did not yet have adequate abilities to develop the church's financial independence in the future. The entrepreneurship education held is limited in curriculum, learning strategies, lecturers who support courses, and the entrepreneurial atmosphere.
\end{abstract}

Keywords: Entrepreneurship Education, theology students, church financial independence

\begin{abstract}
Abstrak. Program Studi (Prodi) Teologi Sekolah Tinggi Teologi (STT) Star's Lub telah menyelenggarakan pendidikan kewirausahaan bagi mahasiswanya. Salah satu tujuannya adalah membekali mahasiswa kemampuan untuk mengembangkan kewirausahaan gereja bila kelak menjadi pendeta. Penelitian ini bertujuan mengetahui sejauhmana pendidikan kewirausahaan tersebut mampu membekali mahasiswa kemampuan untuk mengembangkan kemandirian finansial gereja sebagai bagian dari kewirausahaan gereja. Penelitian dilakukan dua tahap dengan menggabungkan metode kualitatif dan kuantitatif. Tahap pertama meneliti kemampuan kewirusahaan 12 mahasiswa semester akhir yang telah selesai mengikuti pendidikan kewirausahaan dengan fokus pada pengetahuan, keterampilan, dan karakter kewirausahaan. Metode yang digunakan adalah kuantitatif. Tahap kedua menggunakan metode kualitatif dengan meneliti program pendidikan kewirausahaan yang diselenggarakan Prodi Teologi. Informan yang dilibatkan adalah Ketua STT Star's Lub, Wakil Ketua Bidang Akademik STT Star's Lub, dan dosen pengampu mata kuliah kewirausahaan. Hasil penelitian menunjukkan mahasiswa semester akhir STT Star's Lub belum memiliki kemampuan yang memadai untuk kelak mengembangkan kemandirian finansial gereja. Hal tersebut disebabkan pendidikan kewirausahaan yang diselenggarakan juga masih terbatas dari segi kurikulum, strategi pembelajaran, dosen pengampu mata kuliah, dan atmosfer kewirausahaan.
\end{abstract}

Kata Kunci: Pendidikan Kewirausahaan, mahasiswa teologi, kemandirian finansial jemaat 
Kemandirian gereja telah lama menjadi komitmen gereja-gereja di Indonesia. Paling tidak hal itu tercermin dalam Lima Dokumen Keesaan Gereja (LDKG) Persekutuan Gereja-Gereja di Indonesia (PGI): Pokok-pokok Tugas Panggilan Bersama (PTPB), Pemahaman Bersama Iman Kristen (PBIK), Piagam Saling Mengakui dan Saling Menerima (PSMSM), Tata Dasar PGI, dan Menuju Kemandirian Teologi, Daya dan Dana (MKTD2). Rumusan LDKG ini telah dihasilkan sejak tahun 1984 oleh gereja-gereja dalam Sidang Raya X DGI di Ambon (PGI, 2020).

Meskipun Ngaji dan Laukapitang menyebutkan bahwa kemandirian gereja dapat dilihat pada beberapa aspek yaitu penatalayanan, pelayanan, sumber daya, dan ekonomi (Ngaji \& Laukapitang, 2021), namun pada LDGK PGI tersebut nampak bahwa gagasan kemandirian gereja berfokus pada kemandirian teologi, daya dan dana. Artinya bagi PGI kemandirian gereja pada ketiga aspek tersebut sangatlah penting.

Dari ketiga aspek kemandirian gereja menurut $\mathrm{PGI}$ tersebut kemandirian dana tampaknya merupakan aspek yang menjadi pergumulan konkrit gereja-gereja kecil, khususnya yang ada di wilayah pedesaan, di Indonesia. Anggota jemaat gereja-gereja ini umumnya merupakan masyarakat menengah ke bawah atau hidup dalam kemiskinan. Gereja dengan kondisi demikian cenderung tergantung secara finansial kepada pihak atau donatur luar dan kepada anggota jemaat (Sihar, 2013). 
Ketergantungan kepada persembahan anggota jemaat pada akhirnya hanya mendatangkan beban finansial bagi anggota jemaat yang miskin. Di tengah kesulitan mencukupi kebutuhan dasar keluarga, mereka masih harus menanggung beban finansial gereja yang tidak sedikit. Makin sedikit anggota jemaat, makin tinggi beban finansial yang harus ditanggung. Sebab itu, Sihar menyebutkan pentingnya gereja mengupayakan kemandirian finansial. Gereja perlu mengusahakan sumber pemasukan yang baru (Sihar, 2013).

Sederhananya, finansial adalah segala sesuatu yang berkaitan dengan keuangan (KKBI Online, n.d.). Dengan begitu, kemandirian finansial berarti kemampuan untuk mengatur, memenuhi, mengatasi masalah keuangan sendiri sehingga tidak tergantung terhadap orang lain (Band. Qomariyah, 2019). Bagi gereja, kemandirian finansial adalah kemampuan gereja untuk memenuhi, mengatur, dan mengatasi masalah keuangan sendiri tanpa tergantung pada pihak lain.

Gereja yang dimaksudkan di sini adalah gereja sebagai organisasi. Ada beberapa gereja yang telah melakukan usaha tertentu dalam mewujudkan kemandirian finansial tersebut. Gereja Masehi Injili Minahasa (GMIM) membuka Balai Kerja dan Latihan Ketrampilan bagi pemuda gereja. Gereja Masehi Injili di Timor (GMIT) dan Gereja Toraja membuka koperasi. Gereja Kristen Protestan Bali (GKPB) memiliki sejumlah usaha seperti 
perhotelan, wisma, jasa pernikahan, usaha mebel, percetakan, bank, dan lain-lain. (Pasande \& Tari, 2019)

Meskipun belum ada data statistik yang bisa dirujuk mengenai jumlah gereja yang sudah memiliki kegiatan wirausaha, tapi tampaknya belum banyak. Gereja masih menghadapi banyak hambatan dalam menjalankan kegiatan wirausaha. Mulai dari keterbatasan modal usaha, hingga kemampuan sumber daya manusia yang ada dalam gereja untuk menjalankan usaha.

Terkait dengan sumber daya manusia, peran pemimpin gereja sangatlah berpengaruh. Pemimpin gereja yang yang memiliki visi kemandirian finansial gereja dan kemampuan untuk merealisasikannya secara konkrit tentu akan membawa gereja mengatasi hambatan-hambatan kewirausahaan. Sebaliknya, pemimpin gereja yang tidak memilki visi dan kemampuan akan terus berada bersama gereja dengan ketergantungan finansial kepada pihak lain.

Pada umumnya pemimpin gereja adalah pendeta. Simanjuntak memaparkan bahwa sebagai pemimpin gereja, pendeta berperan penting dalam pemberdayaan jemaat dan manajemen pelayanan. Pendeta perlu memberikan pengaruh positif, kepercayaan, dan keyakinan untuk memotivasi jemaat. Pendeta juga dapat mempengaruhi, mengembangkan, 
dan mengarahkan jemaat mencapai suatu keberhasilan bersama (Simanjuntak, 2015).

Kenyataan ini menunjukkan betapa pentingnya peran lembaga pendidikan yang mempersiapkan calon pendeta, yaitu sekolah-sekolah teologi. Materi, metode, dan strategi pembelajaran di sekolah teologi turut menentukan peran yang dapat dimainkan para pendeta di gereja kelak. Pertanyaannya, apakah sekolah teologi sudah mempersiapkan para mahasiswanya dengan pemahaman dan kemampuan praktis berwirausaha? Seberapa besar pemahaman para pengelola sekolah teologi tentang pentingnya membekali mahasiswanya dengan kemampuan berwirausaha? Apakah di dalam kurikulum pembelajaran sudah ada materi wirausaha?

Untuk menjawab pertanyaan-pertanyaan tersebut penulis mengadakan penelitian di Sekolah Tinggi Teologi (STT) Star's Lub Luwuk Banggai pada Program Studi (Prodi) Teologi yang berkedudukan di Sulawesi Tengah. STT ini menarik diteliti karena sudah memiliki satu mata kuliah kewirausahaan yang khusus diadakan bagi mahasiswa prodi teologi. Artinya, STT ini sudah memberi perhatian kepada pendidikan kewirausahaan bagi mahasiswa calon pendeta. Penulis ingin mengetahui sejauhmana pendidikan kewirausahaan yang dijalankan di STT ini mampu membekali mahasiswa kemampuan untuk mengembangkan kemandirian finansial gereja? 
Ganefri dan Hidayat menjelaskan bahwa pendidikan kewirausahaan merupakan proses pembangunan potensi individu berkaitan semua aspek kewirausahaan melalui manajemen, implementasi kurikulum, pedagogi, dan penilaian dalam satu lingkungan yang terstruktur dan terorganisasi (Ganefri \& Hidayat, 2017). Pendidikan kewirausahaan juga merupakan proses pembentukan pola pikir wirausaha, dan membentuk perilaku yang kreatif dan inovatif agar dapat berkreasi serta menciptakan nilai tambah seperti, berani mengambil resiko, dan bisa menghadapi tantangan masa depan yang sangat kompetetif (Susilaningsih, 2015).

Pendidikan kewirausahaan, seperti dikatakan Kasih, harus dirancang dalam suatu sistem yang utuh dan komprehensif untuk memenuhi segala aspek penting yang saling mendukung dan mempengaruhi hasil pembelajaran (Kasih, 2013). Untuk menumbuhkembangkan jiwa kewirausahaan bagi setiap mahasiswa, pendidikan kewirausahaan harus dilakukan secara secara bertahap dan terus menerus atau berkelanjutan selama mereka menempuh pendidikan di kampus (Rifa'i \& Nugraha, 2019).

Ada beberapa aspek penting dalam pendidikan kewirausahaan. Pertama, rancangan kurikulum. Rifa'i dan Nugraha mengemukakan bahwa kelemahan dalam pendidikan kewirausahaan di perguruan tinggi yaitu kurikulum dan materi yang diajarkan dalam mata kuliah kewirausahaan baru sebatas teori di dalam kelas sehingga belum mampu menumbuhkan, 
menanamkan dan menguatkan nilai-nilai kewirausahaan dalam diri mahasiswa (Rifa'i \& Nugraha, 2019).

Mata kuliah kewirausahaan yang diajarkan dengan satu atau dua semeseter belum mampu merubah mindset seseorang. Dengan demikian kurikukulum kewirausahaan harus dirancang melalui beberapa mata kuliah dan bobot sks yang memadai secara berkelanjutan dan ditambah dengan berbagai kegiatan diluar mata kuliah (ekstra kurikuler) untuk mendukung penanaman dan penguatan nilai-nilai kewirausahaan yang harus diperoleh mahasiswa (Kasih, 2013).

Aspek penting kedua dalam pendidikan kewirausahaan di perguruan tinggi adalah metode pembelajaran. Pembelajaran kewirausahaan dengan menggunakan pendekatan teacher centered learning (TCL) yaitu pembelajaran yang berpusat pada guru/dosen perlu diganti dengan student centered learning (SCL) yaitu pembelajaran kewirausahaan yang berpusat pada mahasiswa. Pendekatan TCL dinilai kurang efektif dalam mendorong mahasiswa untuk terlibat aktif dalam membangun pengetahuan, sikap dan perilaku dan sulit untuk memenuhi softskill mahasiswa (Rifa'i \& Nugraha, 2019).

Aspek penting ketiga adalah tenaga pengajar/dosen. Dosen pengampu mata kuliah kewirausahaan mutlak memiliki kompetensi dalam bidang kewirausahaan agar bisa mengasuh mata kuliah kewirausahaan 
dengan baik (Kasih, 2013). Keterbatasan tenaga pengajar dapat diatasi dengan melibatkan tenaga pengajar partime atau tenaga pengajar tamu dari luar kampus seperti para praktisi bisnis/pengusaha, para profesional, atau aumni pengusaha.

Aspek penting yang keempat adalah atmosfer kewirausahaan yang diciptakan perguruan tinggi untuk mendukung pendidikan kewirausahaan. Rifa'i dan Nugraha (2019) menyebutkan ada empat hal yang perlu dilakukan untuk mendukung penyelenggaraan pendidikan kewirausahaan yang efektif seperti: (1) Mendirikan lembaga atau organisasi kewirausahaan; (2) Kerja sama dengan dunia usaha / perusahaan / asosiasi; (3) Kerja sama dengan lembaga keuangan (perbankan / non perbankan); dan (4) Membentuk unit bisnis (perusahaan, koperasi mahasiswa).

Di samping keempat aspek di atas, Kementerian Pendidikan dan Kebudayaan Direktorat Pendidikan Tinggi sudah mengembangkan sebuah program mahasiswa wirausaha untuk mendukung terciptanya lulusan yang siap kerja dan pencipta lapangan kerja yang meliputi: (1) Program mahasiswa wirausaha (PMW); (2) Program kuliah kewirausahaan (KWU); (3) Program magang kewirausahaan (MKU); (4) Program kuliah kerja usaha (KKU); (5) Inkubator wirausaha baru (INWUB) (dalam Wiratno, 2012).

Konsep pendidikan kewirausahaan seperti yang digambarkan di atas penting untuk dijadikan acuan bagi sekolah-sekolah teologi dalam 
mempersiapkan lulusan yang mampu mengembangkan kemandirian finansial gereja. Bagaimana dengan STT Star's Lub Luwuk Banggai? Penelitian ini ingin mengetahui sejauhmana pendidikan kewirausahaan yang dilaksanakan di STT Star's Lub Luwuk Banggai telah mampu mempersiapkan lulusan untuk mengembangkan kemandirian finansial gereja.

Penelitian serupa dengan ini adalah yang dilakukan oleh Fredy Simanjuntak dkk yang berjudul "Menumbuhkan Jiwa Enterpreneurship Mahasiswa STT Real Batam Melalui Kegiatan PKM Tahu Tempe Sebagai Jembatan Pewartaaan Injil". Penelitian ini membahas tentang salah satu program kreatif yang berkaitan dengan kewirausahaan Program Studi Teologi STT Real Batam untuk menilai sejaumana program tersebut berpengaruh terhadap peningkatan motivasi mahasiswa untuk berwirausaha. Penelitian di STT Star's Lub ini berfokus kepada kebijakan pendidikan kewirausahaan secara keseluruhan di Program Studi Teologi dan dikaitkan dengan kemampuan lulusan untuk mengembangkan kemandirian finansial gereja.

\section{METODE}

Penelitian ini menggunakan metode mix kuantitatif dan kualitatif, yaitu perpaduan antara metode kuantatif dengan metode kualitatif (Sugiyono, 2018). Penelitian berlangsung dua tahap. Tahap pertama adalah penelitian kuantitatif yang melibatkan 12 mahasiswa prodi teologi semester 8 untuk 
mengetahui tingkat kesiapan mahasiswa dalam mengembangkan kemandirian finansial gereja. Tahap kedua adalah penelitian kualitatif yang melibatkan Ketua STT Star's Lub, Wakil Ketua Bidang Akademik, dan dosen pengampu mata kuliah kewirausahaan untuk mengetahui program dan kebijakan pendidikan kewirausahaan di kampus ini.

Penelitian kuantitatif menggunakan kuesioner dengan skala likert untuk mengambil data, sedangkan penelitian kualitatif menggunakan teknik wawancara berdasarkan suatu panduan wawancara. Analisis data kuantitatif menggunakan rating scale di mana data akan ditampilkan dalam bentuk presentase angka. Untuk memperoleh frekuensi relatif/angka persenan maka dilakukan perhitungan dengan menggunakan rumus (Sudijono, 2012):

$$
\begin{aligned}
& \mathrm{p}=\mathrm{f} / \mathrm{N} \times 100 \\
& \text { Keterangan: } \\
& \mathrm{f}=\text { Frekuensi yang sedang dicari presentasenya } \\
& \mathrm{N}=\text { Jumlah frekuensi } \\
& \mathrm{P}=\text { Angka persentase }
\end{aligned}
$$

Teknik analisis data kualitatif peneliti menggunakan model Miles and Huberman yang terdiri atas tiga bagian, yaitu reduksi data, penyajian data, dan penarikan kesimpulan (Sugiyono, 2018). 


\section{HASIL PENELITIAN}

\section{Kemampuan Kewirausahaan Mahasiswa}

Hasil penelitian tahap satu yang melibatkan mahasiswa prodi teologi semester 8 menunjukkan bahwa pendidikan kewirausahaan di Prodi Teologi STT Star's Lub belum cukup membekali mahasiswa teologi untuk mengembangkan kemandirian finansial gereja. Hal tersebut dapat dilihat pada beberapa aspek pendidikan yaitu karakter, keterampilan dan pengetahuan kewirausahaan responden.

\section{Karakter Kewirausahaan}

Melalui sebelas butir pernyataan tentang karakter kewirausahaan, satu butir pernyataan memiliki bobot maksimal 60 dan jika ada sebelas penyataan berarti bobot maksimal 660 jika dipersenkan akan menjadi $(660: 660) \times 100=$ 100\%. Namun dari hasil yang didapat bobot total yang di peroleh 411 jika dipersenkan berarti $(660: 411) \times 100=62 \%$. Dari hasil ini peneliti menyimpulkan bahwa sebagian besar responden kurang memiliki karakter kewirausahaan.

Tabel 1. Karakter kewirausahaan responden

\begin{tabular}{|l|l|}
\hline Keterangan & Jarak interval \\
\hline Sangat memiliki (SM) & $595-660$ \\
\hline Memiliki (M) & $463-594$ \\
\hline Kurang memiliki (KM) & $331-462$ \\
\hline Tidak memiliki (TM) & $199-330$ \\
\hline Sangat tidak memiliki (STM) & $132-198$ \\
\hline
\end{tabular}




\begin{tabular}{lll|l|l|l} 
STM & TM & \multicolumn{1}{l}{ KM } & \multicolumn{1}{c}{ M } & SM \\
\hline 132 & 264 & 396 & 411 & 528 & 660
\end{tabular}

\section{Keterampilan Kewirausahaan}

Melalui lima butir pernyataan tentang keterampilan kewirausahaan, satu butir pernyataan memiliki bobot maksimal 60 dan jika ada lima pernyataan memiliki bobot maksimal 300 jika dipersenkan akan menjadi $(300: 300) \times 100=100 \%$. Namun dari hasil yang didapat bobot total yang diperoleh 219 jika dipersenkan berarti $(219: 300) \times 100=73 \%$. Dari hasil ini peneliti menyimpulkan bahwa sebagian besar responden memiliki keterampilan kewirausahaan.

Tabel 2. Keterampilan kewirausahaan responden

\begin{tabular}{|l|c|}
\hline \multicolumn{1}{|c|}{ Keterangan } & Jarak interval \\
\hline Sangat memiliki (SM) & $271-300$ \\
\hline Memiliki (M) & $211-270$ \\
\hline Kurang memiliki (KM) & $151-210$ \\
\hline Tidak memiliki (TM) & $91-150$ \\
\hline Sangat tidak memiliki (STM) & $60-90$ \\
\hline
\end{tabular}

\begin{tabular}{lll|l|ll} 
STM & TM & KM & M & SM \\
\hline 60 & 120 & 180 & 219 & 300
\end{tabular}




\section{Pengetahuan Kewirausahaan}

Melalui lima butir pernyataan tentang pengetahuan kewirausahaan, satu butir pernyataan memiliki bobot maksimal 60 dan jika ada lima pernyataan memiliki bobot maksimal 300 jika dipersenkan akan menjadi $(300: 300) \times 100=100 \%$. Namun dari hasil yang didapat bobot total yang

diperoleh 147 jika dipersenkan berarti $(147: 300) \times 100=49 \%$. Dari hasil ini peneliti menyimpulkan bahwa sebagian besar responden tidak memiliki pengetahuan kewirausahaan.

Tabel 3. Pengetahuan Kewirausahaan Responden

\begin{tabular}{|l|c|}
\hline \multicolumn{1}{|c|}{ Keterangan } & Jarak interval \\
\hline Sangat memiliki (SM) & $271-300$ \\
\hline Memiliki (M) & $211-270$ \\
\hline Kurang memiliki (KM) & $151-210$ \\
\hline Tidak memiliki (TM) & $91-150$ \\
\hline Sangat tidak memiliki (STM) & $60-90$ \\
\hline
\end{tabular}

\begin{tabular}{ll|l|llll} 
STM & \multicolumn{1}{l}{ TM } & \multicolumn{1}{l}{ KM } & M & SM \\
\hline 60 & 120 & 147 & 180 & 240 & 300
\end{tabular}

Dari aspek pengetahuan, ketrampilan, dan karakter yang digambarkan di atas dapat disimpulkan bahwa responden belum memiliki kompetensi wirausaha yang memadai. Dengan begitu sulit diharapkan kelak ketika menjadi pendeta mereka bisa mengembangkan kemandirian finansial jemaat. 


\section{Pendidikan Kewirausahaan di STT Star's Lub}

Penelitian tahap kedua dilakukan melalui wawancara dengan tiga informan yaitu, Ketua STT Star's Lub, Wakil Ketua Bidang Akademik, dan dosen pengampu mata kuliah mengenai proses pendidikan kewirausahaan yang diselenggarakan oleh perguruan tinggi bagi prodi teologi. Hasil penelitian dirangkum pada pemaparan berikut ini.

Pendidikan kewirausahaan prodi teologi sudah ada dalam kurikulum yang direalisasikan melalui mata kuliah kewirausahaan dengan dua SKS yang diikuti oleh mahasiswa semester tujuh, seperti dikemukakan oleh Wakil Ketua Bidang Akademik. Untuk satu mata kuliah terdiri dari enam belas kali pertemuan sudah termasuk Ujian Tengah Semester (UTS) dan Ujian Akhir Semester (UAS). Jadi pertemuan untuk pembelajaran maksimal hanya 14 kali pertemuan (Lepong-Bulan, wawancara, April 2021). Hal itu juga dibenarkan oleh dosen pengampu mata kuliah kewirausahaan (Mosooli, wawancara, Mei 2021).

Untuk strategi pembelajaran kewirausahaan, Ketua STT Star's Lub mengatakan bahwa untuk saat ini baru sebatas pengadaan satu mata kuliah kewirausahaan. Usaha yang dikembangkan mahasiswa teologi belum ada. Kerjasama dengan dunia usaha juga belum dilakukan. "Masih dalam proses baru memulai" (Pasande, wawancara, April 2021). Hal ini diakui juga oleh 
dosen pengampu mata kuliah kewirausahan (Mosooli, wawancara, Mei 2021).

Dari sisi kompetensi dosen pengampu mata kuliah kewirausahaan, Wakil Ketua Bidang Akademik mengemukakan kompetensi dosen tersebut bukan di bidang kewirausahaan. "Sebenarnya bukan sih, dia kan M.Si teologi begitu ya" (Lepong-Bulan, wawancara, April 2021). Dalam wawancara, dosen tersebut mengakui bahwa memang dia tidak memiliki kompetensi dari sisi keilmuan untuk mengampu mata kuliah kewirausahaan. Namun dari sisi pengalaman praktis beliau pernah mengelola sebuah kecil milik pribadi. "Karna itu mungkin saya dipilih sebagai pengampu mata kuliah ini. Saya pernah punya pengalaman mengelola usaha kecil" (Mosooli, wawancara, Mei 2021).

Dosen pengampu mata kuliah kewirausahaan menjelaskan bahwa metode yang dia gunakan masih lebih banyak di dalam kelas, diskusi, membaca dan memahami teks, dan masih berpusat pada dosen. Ada juga praktik tetapi dalam rentang waktu yang pendek (Mosooli, wawancara, Mei 2021).

Hasil wawancara ini memberikan penjelasan mengenai penyebab responden belum memiliki kompetensi wirausaha untuk kelak dapat mengembangkan kemandirian finansial gereja. STT Star's Lub sebagai lembaga yang mempersiapkan mereka menjadi calon pendeta, belum 
memberikan bekal yang cukup. Pendidikan kewirausahaan yang diselenggarakan masih sangat minim, baik dari segi kurikulum, metode pembelajaran, tenaga pengajar, maupun kerjasama dengan dunia usaha.

\section{PEMBAHASAN}

\section{Pendidikan Kewirausahaan dalam Kurikulum Sekolah Teologi}

Dari paparan hasil penelitian di atas nampak bahwa porsi untuk pendidikan kewirausahaan dalam kurikulum STT Star's Lub masih sedikit. Hanya satu mata kuliah dengan bobos dua SKS. Padahal seperti dikatakan Kasih (2013), pembelajaran kewirausahaan harus memiliki bobot SKS yang memadai dan belajar secara berkelanjutan. Bahkan Tilaar mengatakan bahwa pembelajaraan kewirausahaan harus dirancang dari semeseter awal hingga akhir (Tilaar, 2012). Sementara mata kuliah kewirausahaan di STT Star's Lub diberikan pada waktu menjelang semester akhir, yaitu semester tujuh, bukan pada semester awal.

Tampaknya hal tersebut merupakan bagian dari realita sekolahsekolah teologi, khususnya program studi teologi, pada umumnya yang belum terlalu memberi perhatian kepada pendidikan kewirausahaan. Walaupun belum ada riset khusus mengenai hal tersebut yang dapat dirujuk, namun patut diduga bahwa muatan kurikulum prodi teologi pada umumnya masih memberikan porsi terbesar pada pembelajaran dogma. 
Dalam studi dokumen terhadap Kurikulum Prodi Teologi STT Star's Lub yang sementara digunakan pada saat penelitian ini dilakukan, tampak bahwa pembelajaran dogma masih dominan. Kurikulum tersebut terdiri atas 71 mata kuliah dengan 156 SKS (sistem kredit semester). Dari jumlah ini, 39 mata kuliah atau sebanyak 54\% merupakan mata kuliah teologi sistematika, teologi praktika, dan biblika. Ketiga kelompok mata kuliah ini merupakan materi pembelajaran dogma. Sementara itu 21 mata kuliah atau sebanyak 29\% adalah mata kuliah dasar/umum, metode penelitian, dan praktek. Sisanya 11 mata kuliah atau sebanyak 15\% merupakan mata kuliah yang berkaitan dengan Pendidikan dan Pendidikan Agama Kristen.

\section{Metode Pembelajaran Kewirausahaan}

Metode pembelajaran kewirausahaan, menurut Rifa'i dan Nugraha (2019), harus menempatkan peserta belajar sebagai pusat pembelajaran supaya bisa mendorong mahasiswa terlibat aktif sehingga memenuhi softskill mereka. Namun berdasarkan hasil wawancara dengan dosen pengampu mata kuliah kewirausahaan, tampak bahwa pembelajaran kewirausahaan masih berpusat pada dosen.

Tampaknya hal ini diakibatkan oleh kompetensi yang dimiliki oleh dosen pengampu mata kuliah tersebut, belum tersedianya sarana pendukung untuk pembelajaran di luar kelas, dan terbatasnya waktu. Ciputra mengatakan bahwa jika kampus ingin mengembangkan kewirausahaan bagi 
mahasiswa, maka kampus perlu diadakan pusat pengembangan bisnis di dalam kampus (dalam Tilaar, 2012).

Pendapat Ciputra tersebut menyaratkan adanya sarana pra-sarana yang memadai dan sumber daya manusia pengelola yang berkompeten, serta didukung oleh sumber dana yang cukup. Namun seperti dikatakan Imeldawati, perguruan tinggi teologi yang umumnya dikelola oleh pihak swasta, baik gereja atau yayasan interdenominasi, menghadapi banyak kendala SDM, dana, sarana dan prasarana (Imeldawati, 2019).

\section{Dosen Kewirausahaan}

Untuk menjadi mengampu mata kuliah kewirausahaan, seorang dosen mutlak memiliki kompetensi dalam bidang kewirausahaan (Kasih, 2013). Kompetensi ini bisa dari segi pendidikan akademis maupun pengalaman praktis sebagai pengusaha yang sudah terbukti berhasil mengelola dan menjalankan usaha. Namun untuk memenuhi hal ini sekolah teologi kembali menghadapi kendala. Keterbatasan dana salah satu faktor penyebab sekolah teologi kurang mampu menyediakan dosen kewirausahaan dengan kompetensi memadai (band. Imeldawati, 2019). Hal ini nampak dari keberadaan dosen pengampu mata kuliah kewirausahaan di STT Star's Lub. Apalagi ditambah kenyataan bahwa kewirausahaan belum menjadi prioritas dalam pembelajaran mahasiswa di kampus. 


\section{Kerjasama dengan Dunia Usaha}

Mengingat berbagai keterbatasan yang dihadapi oleh sekolah teologi maka tampaknya kerjasama dengan dunia usaha merupakan sebuah peluang yang potensial. Kerjasama tersebut dapat berupa kegiatan magang mahasiswa, pendampingan rintisan usaha mahasiswa pada program inkubator usaha, keterlibatan praktisi usaha sebagai mentor, dan lain-lain.

Namun tampaknya hal ini belum dikerjakan oleh Program Studi Teologi STT Star's Lub. Masih perlu perumusan konsep kerjasama yang jelas, identifikasi usaha-usaha potensial di sekitar kampus, dan penyiapan SDM yang kompeten dalam pengadaan dan pengelolaan kerjasama tersebut.

\section{KESIMPULAN}

Berdasarkan uraian pada bagian HASIL dan PEMBAHASAN di atas maka peneliti menyimpulkan bahwa pendidikan kewirausahaan prodi teologi belum cukup membawa kemandirian finansial dalam jemaat. Hal tersebut dapat dilihat dari hasil pendidikan kewirausahaan mahasiswa teologi semester 8 yang menjadi responden dalam penelitian yaitu sebagian besar kurang memiliki karakter kewirausahaan, dan sebagian besar tidak memiliki pengetahuan kewirausahaan. Hal itu disebabkan oleh kurikulum kewirausahaan prodi teologi kurang memadai, belum ada unit usaha yang dikembangkan oleh prodi teologi, dan metode pembelajaran kewirausahaan kurang memadai. 
Dengan demikian untuk menghasilkan lulusan yang bisa berkontribusi dalam jemaat untuk memecahkan persolan dengan tidak kebergantungan dari pihak lain maupun dari pemberian jemaat, maka kurikulum kewirausahaan prodi teologi harus memadai, terbentuknya unit usaha yang dikembangkan oleh prodi teologi, dosen pengampu mata kuliah memiliki kompetensi di bidang kewirausahaan, dan metode pembelajarannya harus memadai juga disertai dengan praktik/ magang.

\section{DAFTAR PUSTAKA}

Ganefri, \& Hidayat, H. (2017). Perspektif Pedagogi Entrepreneurship di Pendidikan Tinggi. Kencana.

Imeldawati, T. (2019). Manajemen Perguruan Tinggi Teologi. KERUGMA: Jurnal Teologi dan Pendidikan Agama Kristen, 1(1), 61-74. http://www.sttiimedan.ac.id/e-journal/index.php/kerugma/article/view/6

Kasih, Y. (2013). Mewujudkan Pendidikan Kewirausahaan Di Perguruan Tinggi Melalui Proses Pembelajaran yang Berkelanjutan. Forum Bisnis Dan Kewirausahaan Jurnal IImiah STIE MDP, 2(2), 164-182.

KKBI Online. (n.d.). Arti Kata Finansial. Kamus Besar Bahasa Indonesia (KBBI). Diambil 5 November 2021, dari https://kbbi.web.id/finansial

Ngaji, P., \& Laukapitang, Y. D. (2021). Korelasi Praktik Entrepreneurship Terhadap Kemandirian Gereja IFGF di Flores Jemaat Maumere. Repository STT Jaffray, 3(1). https://skripsi.sttjaffray.ac.id/index.php/skripsi/article/view/110

Pasande, P., \& Tari, E. (2019). PERAN GEREJA DALAM PENGEMBANGAN PROGRAM KEWIRAUSAHAAN DI ERA DIGITAL. Visio Dei: Jurnal Teologi Kristen, 1(1), 38-58.

PGI. (2020). Dokumen Keesaan Gereja Persekutuan Gereja-Gereja di Indonesia (DKG-PGI) 2019-2024. BPK Gunung Mulia.

Qomariyah, D. N. (2019). PEMBERDAYAAN PEREMPUAN DAN KEMANDIRIAN DALAM HOME INDUSTRI KRUPUK DI LINGKUNGAN KARANGMLUWO MANGLI JEMBER. An-Nisa': Jurnal Kajian Islam \& 
Gender, 11(2), 158. https://doi.org/10.35719/ANSA.V1112.779

Rifa'i, A., \& Nugraha, T. E. (2019). Rencana Strategi Dalam Menerapkan Pendidikan Kewirausahaan Di Perguruan Tinggi Melalui Proses Pembelajaran yang Berkelanjutan. (Studi Kasus Pada Universitas Banten Jaya Kota Serang-Banten). Jurnal Manajemen dan Bisnis, 1(2), 71-90. https://ejournal.lppm-unbaja.ac.id/index.php/jmb/article/view/1231

Sihar, O. I. J. L. (2013). Penatalayan dan Kemandirian Gereja (Suatu studi tentang peranan penatalayanan gereja di dalam usaha pencapaian kemandirian gereja dalam bidang dana di GPIB Kasih Karunia Medan) [Program Studi Teologi $\quad$ FTEO-UKSW]. https://repository.uksw.edu/handle/123456789/6879

Simanjuntak, W. C. (2015). Kepemimpinan Pendeta dalam Pelayanan GPIB Jemaat Siloam Kerayan - Kalimantan Timur dari Prespektif Kepemimpinan Transformasional [Fakultas Teologi Universitas Kristen Satya Wacana]. https://repository.uksw.edu/handle/123456789/9921

Sudijono, A. (2012). Pengantar Statistik Pendidikan. Raja Grafindo Persada.

Sugiyono. (2018). Metode Penelitian Kuantitatif, Kualitatif, dan R\&D. Alfabeta.

Susilaningsih. (2015). Pendidikan Kewirausahaan Di Perguruan Tinggi: Pentingkah Untuk Semua Profesi? Jurnal Economia, 11(1), 1. https://doi.org/10.21831/economia.v11i1.7748

Tilaar, H. A. R. (2012). Pengembangan Kreativitas dan Entrepreneurship dalam Pendidikan Nasional. Kompas. https://komunita.widyatama.ac.id/pengembangan-kreativitas-danentrepreneurship-dalam-pendidikan-nasional/

Wiratno, S. (2012). The implemtation of enterpreneurship education in the higher education. Jurnal Pendidikan dan Kebudayaan, 18(4), 453-466. 